\title{
The First Peoples Principles of Learning: An Opportunity for Settler Teacher Self-Inquiry
}

\author{
Kelly Hanson
}

\begin{abstract}
In 2016, the province of British Columbia introduced a redesigned K-6 curriculum. Undergirding this plan is the learning philosophy, the First Peoples Principles of Learning. This paper is written from the perspective of a settler teacher as she engages in self-study research to develop her understanding of the curricular plan. The author describes her emerging self-awareness as opening to a deeper understanding of her Euro-American worldview, cultural narratives that maintain gaps between settler teachers and First Peoples perspectives, and how ongoing self-inquiry is a way to improve as an educator.
\end{abstract}

\section{Background}

The First Peoples Principles of Learning (FPPL) (FNESC, 2014) is the learning philosophy underpinning British Columbia's (BC) recently redesigned curriculum. The FPPL are nine principles that explain what a First Peoples approach to learning is: supports, involves, recognizes, and embeds (FNESC, 2008/2014, Appendix A). Posters displaying the principles are found across BC in learning spaces such as K-12 classrooms, school district board offices, and faculties of education. Yet, despite the prolific access to the principles, there is uncertainty amongst many teachers regarding how to enact the principles. In part, the challenge is that the FPPL is not a set of lesson or unit plans, but rather a guide that requires teacher understanding to translate the principles into choices about what is important to learn and how to be responsive within their own contexts (Chrona, 2015). As a settler educator during this time of curricular transformation, I wondered what kinds of learning conditions and supports I would need to better understand the principles. I questioned how I could humbly, and without appropriation, live the principles through my teaching practice.

Finding ways for all teachers to embody First Peoples approaches to learning across the province is important. At present, First Peoples children and youth across Canada experience a consistent lack of consideration of their perspectives in public schools, which has a significant, detrimental impact. Tanaka (2016) writes,

Too often, habits of the dominant culture are privileged to the exclusion or detriment of other cultural ways of knowing brought into the classroom by students. In Canada, in the case of Aboriginal learners, this presents a particularly poignant case: as one of the fastest growing student populations, Aboriginal learners continue to face significant struggles in school disproportionate to those faced by the larger student body. (pp. 5-6) 
By weaving FPPL into all aspects of the curriculum, the BC Ministry of Education (2015) attempts to acknowledge the deep value of First Peoples perspectives (pp. 6-7). Now, it is up to educators to act out the needed changes to their pedagogy that will recognize, embrace, and make accessible First Peoples content and perspectives for all students.

The intention of this article is to share my learning as a way to inspire more conversation about how teachers from all cultures and backgrounds can engage in self-inquiry as a way to better understand and live the principles in their classrooms. From the beginning of my inquiry, I realized there was not one way for settler teachers to learn, but I believed that developing greater self-awareness and grappling with the teaching tendency to "teach who we are" (Palmer, 1998, p. 1) was an important starting point. According to Palmer, good teaching comes from the identity and integrity of teachers who are aware of the influence of their inner life on their teaching relationships (p. 12). In my experience, self-awareness that is developed through the mindful interrogation of my beliefs, blind spots, and taken-for-granted understandings renews my capacity to engage students more fully and honestly by making sound connections between students and subject matter (Hanson, 2017, pp. 6-7).

My self-inquiry into the FPPL challenged my inner world and ways of knowing. Identifying my settler standpoint and how this lineage was fraught with acts of injustice toward First Peoples raised much uncertainty and discomfort for me. I felt I was continually falling short; the little I knew about First Peoples history, culture, and perspectives made me feel self-conscious as I tried to live up to my responsibility to learn and grow my teaching practice to support FPPL. However, rather than embracing the reluctance and crisis of confidence that went along with honestly positioning myself centrally in my inquiry, I aimed to create a meaningful, accessible account of my learning that could sensitize readers to some of the issues of settler teachers engaging in First Peoples curricula. Rather than be shrouded in silence for fear of getting it wrong, I decided to give voice to my situated ways of knowing - a practice that involved me restorying my fear. To shift my language and my mindset, I drew on Martusewicz's (2001) description of openings to describe my experiences, rather than shortcomings. Openings are the possibilities for growth and renewal that are created through the ongoing, interpretive, nature of sense-making. Martusewicz describes that an opening is the result of a process that creates more connections in our understandings. She writes,

Opening requires the constant reinvention of thought and consequently the freedom of thought. For educators interested in social justice, this requires that we understand the potential in our relations with students for infinite creation of new ideas... It also requires that we recognize those forms, behaviours, and processes that might shut down or block these creative possibilities. (p. 10)

For me, the openings created through my self-inquiry foregrounded an appreciative, life-giving commitment to learning more. In what follows, I describe how rather than resisting the revised curricula by continuing to teach in my own style, as is often a teacher's response to curricular change (Broom, 2016, pp. 722-723), I learned about myself in relation to the First Peoples Principles of Learning. I chose not to ignore what I did not know or understand, and I opened to an awareness of my 
The First Peoples Principles of Learning: An Opportunity for Settler Teacher Self-Inquiry

Euro-American settler worldview, to common cultural narratives that maintained gaps between settler and First Peoples content and perspectives, and to ongoing inquiry.

\section{Opening to the First Peoples Principles of Learning}

The First Peoples Principles of Learning were developed by the First Nations Education Steering Committee (FNESC), an independent, nonprofit organization comprising 111 members from diverse First Nations communities working on behalf of First Nations education in BC since 1992. Grass (2017) describes that FNESC continually aims to develop a variety of unique structures and strategies for First Peoples education and to do so they present a united voice based on common understandings and beliefs held among the many diverse nations (p. 4). ${ }^{1}$

Initially, FNESC created The First Peoples Principles of Learning to support the course, English 12 First Peoples (FNESC, 2008), which explored First Peoples literature. The FPPL were a support to guide BC teachers to consider beyond what we teach, through the lens of how we teach. For example, reading a First Peoples story followed by a multiple-choice comprehension quiz does not approach learning through attending holistically to the unique mind, body, spirit, community, and land relations that are integral to how students read and interpret the world.

The principles led teachers and students to learn through stories while making connections to their own identities, and with the opportunity to follow the consequences of actions. Almost a decade after the creation, the principles were used to inform the provincial curricular reform (BC Ministry of Education, 2015, pp. 6-7). Thus, all curricular content has the opportunity to be explored through an understanding of learning as developing connectedness and reciprocal relationships. Relationships that reveal themselves, over time and with patience, through memory, story, and history (FNESC, 2008/2014).

The approach to learning described in the FPPL resonated with me as a teacher who has aimed to live education as a holistic endeavor. I trace the kinship I have felt back to my childhood experiences with schooling and continual relocation. Beginning at an early age and continuing until my high school graduation, my family moved within Canada and internationally. Experiences of displacement added complexity to my sense of my identity, belonging, and my (dis)connection with school. Although I always loved to learn, my time in classrooms taught me that school is separate from life at home and from my other lived experiences. From the perspective of the new student, I learned that classrooms can deny and silence the multiple, holistic experiences of children by overemphasizing the cultural norms of the dominant society. These early memories of being a newcomer and outside of the taken-for-granted culture of the different schools I attended were integral to how I engaged in teaching and learning as an adult and why I came to see myself as a teacher who intends to be responsive to her students and their biographies and histories.

However, as I learned more about what it meant to be a settler educator and about settler relationality, the common ground I initially experienced with the principles gave way to my understanding that there is much for me to learn about the nature of the First Peoples Principles of Learning and my relation to 
them. Regan (2010), a settler and former residential schools claims manager, shares that settlers must undergo their own process of decolonization by which they change the way that they see themselves and the way they learn (p. 11). She also writes, "my own deepest learning has always come when I was in unfamiliar territory culturally, intellectually, and emotionally. It seems to me that the space of not knowing has power that may hold a key to decolonization for settlers" (p. 18).

For me, knowing myself as a settler educator was part of embracing an unfamiliar territory and a new way of seeing my identity. Snelgrove, Dhamoon, and Corntassel (2014) explain that a settler is a person who is named by "virtue of living and owning land appropriated from Indigenous peoples, as well as exercising and seeking rights that are collectively denied to Indigenous peoples" (p. 13). By calling myself a settler educator, I learned to describe myself in specific relation to land and contemporary Euro-American knowledge. More specifically, I moved away from myths of settler Canadians as primarily peacemakers and acknowledged the destructive legacy of destroyed, ignored, and devalued Indigenous experiences. As a settler educator, I have had the privilege of teaching in accordance with a naturalized worldview that does not easily recognize the responsibilities of settlers and the extent of settler injustices. Veracini (2011) explains that, "settlers do not discover: they carry their sovereignty and lifestyles with them... As they move towards what amounts to a representation of the world, as they transform the land into their image, they settle another place without moving" (p. 206).

By asking questions about my settler relationships, my understanding of myself began to unsettle or, put another way, open. I became open to the realization that despite the experiences growing up that I thought helped me recognize the gaps between school and home and my strong desire and commitment to child-centered learning, I still needed to reimagine who I am and who I want to be through the lens of being a settler. Without attempting to shed my privileged settler ways of knowing, I was at continual risk of contributing to a reproduced settler worldview that involved inherited, preconceived expectations that were outside of my awareness.

\section{Opening One: Everyone Has a Worldview}

Understanding that a First Peoples approach to learning is holistic and strength-based, led me to ask myself what are other approaches to learning in schools by contrast? This question was an opportunity to consider the "privilege of not having to know, name, or otherwise mark [my] subjectivity and positionality relative to the ongoing project of settler colonialism" (Cannon, 2013, p. 22). As I reviewed the principles, I called into question how learning is approached through a dominant culture lens in my classroom. While I do not relish binary thinking, I began to map my understanding of the FPPL by recognizing and naming the implicated worldview in all approaches to learning. The following chart draws contrasts between a dominant, Euro-American approach to learning described by Sanford, Williams, Hopper, and McGregor (2013, p. 21) with the First Peoples Principles of Learning (FNESC). 


\begin{tabular}{|c|c|}
\hline Dominant Approach to Learning & First Peoples Principles of Learning (FNESC) \\
\hline $\begin{array}{l}\text { Learning is competitive, individualistic. } \\
\text { The goal of learning is to get a job. }\end{array}$ & $\begin{array}{l}\text { Learning ultimately supports the well-being of the self, } \\
\text { the family, the community, the land, the spirits, and } \\
\text { the ancestors. }\end{array}$ \\
\hline $\begin{array}{l}\text { Knowledge is transmitted. } \\
\text { Students work independently. } \\
\text { Teaching and assessment are separate. }\end{array}$ & $\begin{array}{l}\text { Learning is holistic, reflexive, reflective, experiential, } \\
\text { and relational (focused on connectedness, on } \\
\text { reciprocal relationships, and a sense of place). }\end{array}$ \\
\hline $\begin{array}{l}\text { Learning is teacher-to-student focused. } \\
\text { Teacher chooses what student learn. }\end{array}$ & $\begin{array}{l}\text { Learning involves recognizing the consequences of } \\
\text { one's actions. } \\
\text { Learning involves generational roles and } \\
\text { responsibilities. }\end{array}$ \\
\hline Euro-American knowledge focus. & Learning recognizes the role of Indigenous knowledge. \\
\hline $\begin{array}{l}\text { Focus of learning is on a single discipline, in a } \\
\text { linear fashion. }\end{array}$ & Learning is embedded in memory, history, and story. \\
\hline $\begin{array}{l}\text { Students are ranked according to predetermined } \\
\text { criteria. }\end{array}$ & $\begin{array}{l}\text { Learning involves patience and time. Learning requires } \\
\text { exploration of one's identity. }\end{array}$ \\
\hline Teacher is the expert and all-knowing. & $\begin{array}{l}\text { Learning involves recognizing that some knowledge is } \\
\text { sacred and only shared with permission and/or in } \\
\text { certain situations. }\end{array}$ \\
\hline
\end{tabular}

Fig. 1: Contrasting worldviews in teaching and learning

I share this comparison because my settler privilege of not having to name my worldview was challenged when I contrasted the two side by side in Figure 1. Before I had juxtaposed what is considered to be a dominant approach to learning with the principles, I lacked an appreciation of the differences between the two and a language to reflect how my beliefs and practices are part of the dominant view.

Making my settler worldview visible was an opportunity to create an authentic bridge to the First Peoples Principle of Learning, rather than develop FPPL within my existing dominant framework of learning. With greater awareness of distinctiveness, I moved away from what Battiste (2011) calls "cognitive imperialism" - a universalized approach to knowledge that denies the multiple of ways of knowing that students bring into schools. I agree with Battiste's assertion that cognitive imperialism is a form of racism that is characterized by a lack of understanding of the complexities of modern thought by marginalizing all non-Western forms of thinking. Battiste writes that cognitive imperialism is "forced assimilation... 'white-washing' the brain' (p. XIX) and Nishnaabeg scholar Simpson (2014) offers an example of the forced assimilation she experienced in schools,

My experience of education from kindergarten to graduate school was one of coping with someone else's agenda, curriculum, and pedagogy, someone who was neither interested in my homeland, my language or history, nor my Nishnaabeg intelligence. No one ever asked me what I was interested in nor did they ask me for my consent to participate in their system. (p. 6)

Seeing the classroom through Simpson's description of her school experiences, I challenged myself to recognize the ways that I have mistakenly promoted, and thus protected, colonialism by not making explicit that I am always teaching in relationship to a worldview. For example, as opposed to recognizing the role of Indigenous knowledge, I have normalized and reproduced my settler perspective through homogeneous accounts of history, science, and geography. I have taught practices of mapping and naming in geography with such certainty that there was little to no opportunity for students to question 
these Euro-American epistemologies. I have done this despite my commitment to inquiry and holistic education. Comparing worldviews helped me to articulate how universalized approaches to knowledge validate one source of knowledge and power and are a form of cognitive manipulation used to discredit other knowledge bases. My inquiry into the FPPL was an opportunity to challenge the normalcy of the dominant worldview in order to serve the needs of all students moving forward.

\section{Opening Two: Interrogating Narratives That Divide}

Understanding differences in worldview was important to my self-awareness. However, I have also learned we can be negatively divided by our differences through the stories we tell in schools. Donald (2012) describes that storytelling in Canadian society has developed through colonial frontier logic; a mythological narrative that began with perceptions of fur-trade forts as sites of equal opportunity in Canada. Colonial frontier logic posits that everyone had the opportunity to build the forts that grew into what settlers describe as civilization. Through such storytelling, Canadian students have been taught to celebrate civilization processes such as the fort and to see them as the standard for progress and development wherein "European Global Exploration $=$ Trade $=$ Settlement $=$ Cultural Diffusion $=$ Civilization $=$ Progress $=$ Freedom $=$ Economic Prosperity $=$ Development" (p. 96). As the story goes, once the inside of the fort is established, it is maintained, protected, and privileged, and those outside the fort are understood as having lacked a desire and ability to progress and develop. Importantly, for the ongoing perpetuation of colonial frontier logic, anyone who tries to reject this story is understood to be against freedom and economic prosperity and, thus, these settler narratives and perspectives "have calcified into reductive mythologies that substantiate colonial claims of entitlement and superiority" (Decter \& Isaac, 2015, p. 102).

As I have discussed, The First Peoples Principles of Learning describe learning as dependent upon connectedness, on reciprocal relationships, and a sense of place. Through awareness of divisive cultural narratives, such as that of the colonial fort, I learned to better honour FPPL by sharing stories in my classroom that illustrate how settlers and First Peoples have a "long history of contact, collaboration, cooperation, integration" (Scott, 2013, p. 35). One way to share stories to this effect is through Indigenous Métissage, which is a method of story inquiry that,

Involves the purposeful juxtaposition of mythic historical perspectives (often framed as commonsense) with Aboriginal historical perspectives. The ethical desire is to reread and reframe historical understanding in ways that cause readers to question their own assumptions and prejudices as limited and limiting, and thus foster a renewed openness to the possibility of broader and deeper understandings that can transverse perceived cultural, civilizational, and temporal divides (Donald, 2009, pp. 5-6)

Over the course of my inquiry, I read a variety of Indigenous Canadian literature that depicted how First Peoples cultures, perspectives, and histories developed in relationship to settler societies. Donald (2012) offers that within the emergence of an awareness of connections and relationships resides a needed, "new or renewed ethical framework that clarifies the terms of which we can speak to each other" (p. 103). Further, he describes ecological imagination-when community members see themselves as 
part of the living system of the world, and see each other, not as the same but as interconnected, as an indicator of such an ethic (p. 103). With an ethic of ecological imagination, balance and reciprocity are key, and either/or frameworks including insider/outsider and us/them binaries are abandoned. Moving forward, I hope I can inspire such imagining with my students through how we experience relationships between diverse groups of people in our classroom storytelling.

Looking back at my inquiry, I notice that when I explored my dominant worldview I focused on differences, but when I considered fort logic, I challenged myself to imagine my relatedness to the principles. It seems that over time, I moved beyond either/or frameworks to embrace narratives where the complexity of shared histories is centralized. As I paid attention to how my thinking changed, knowledge was revealed to be in constant motion and constructed as my interpretation of my identity and experiences collided. With reflection, new questions and new understandings of the principles were possible.

The final opening to share is the importance of inquiry as an ongoing process. It is my stance that all arrived at (and inherited) understandings should facilitate opportunities for further listening and inquiry. Thus, while attention to worldviews and cultural narratives increased my understanding of FPPL, there is always much more to learn.

\section{Opening Three: Inquiry as Ongoing}

My self-inquiry was dependent on learning with others. I learned about myself as I discussed the First Peoples Principles with members of my district Indigenous Education department, attended community workshops, and engaged with educational theories. For me, collaboration is at the heart of ongoing inquiry. It is not a tool for problem-solving, but rather an act of reorienting my thinking again and again through relationship making and dialogue. Within my interchanges around FPPL, there was great healing and growth that was not necessarily about the inclusion of First Peoples perspectives to repair loss or damage, but was the result of a move towards what Hargreaves and Jefferess (2015) describe as, "a transformed order of social relations" wherein reconciliation of settler and First Peoples perspectives is "always beginning" in the present moment and context (p. 208).

In my inquiry, collaboration was an example of a "transformed order of social relations" (Hargreaves \& Jefferess, 2015, p. 208) because through my interactions I embraced my teacher learning as interdependent with the ever-changing needs, perspectives, strengths of my communities and students. I was not looking for ways that colonialism could be solved through expertise. Rather through active collaboration and ongoing inquiry, I experienced reconciliation as a human endeavor that is always incomplete and thus always required ongoing attention and awareness to context. I was not looking to become an expert, but rather focused on growing personal qualities such as attunement, mindfulness, and question asking.

Further, the sentiment "always beginning" (Hargreaves \& Jefferess, 2015) is important to my experience. The term brings to mind the contemplative, mindful, perspective of a beginner's mind that supports ongoing inquiry. Beginner's mind is a way of looking at the present moment without bringing forward 
assumptions and habits that already are established. When I looked at my understanding of FPPL through the lens of beginner's mind, the following questions emerged as a daily practice:

- How is what I am teaching related to nurturing well-being for myself, my students, our community, and the greater world?

- Where am I learning, and what is my relationship to this land? How do these relationships represent the consequences of our actions?

- How am I considering multiple generations in my learning?

- To what extent am I considering and appreciating Indigenous knowledge in my teaching and learning?

- What stories am I learning from, sharing, and creating?

- What is my relationship to time? Am I acting with patience?

- Who am I at this moment and who do I want to be?

By asking these questions again and again in my teaching context, I hoped to continually move away from habitual ways of teaching that reproduce settler worldview and fort narratives through the obscuring and marginalizing of First Peoples content and perspectives. Without such ongoing questioning, awareness can stagnate and the possibilities of nurturing the strengths and identities of students in meaningful ways that connect them to their communities and the natural world will be missed. I do not believe that there is one best way to achieve such awareness; attention to worldview, story, and inquiry have been mine, but learning takes many paths. However, I do know that teachers' responsiveness to the learning needs of First Peoples students and communities is critical to the future learning of all and, thus, this conversation must continue.

\section{Reciprocating the Gift of First Peoples Principles of Learning}

The FPPL is not a stand-alone addition to the classroom but a shared foundation, a gateway to paying closer attention to learning from identity, land, story. I have imagined that the curricula that will emerge from points of contact between teachers, students, and FPPL will foster ethics that are based on new understandings of more equitable ways to embrace learning in schools. The FPPL presented me with an opportunity to examine my teaching practice and, by extension, what Hargreaves and Jefferess (2015) call the "frameworks by which non-Indigenous peoples imagine themselves, and the nation" (p. 204). Engaged with self-awareness, the principles were a guide to improve my capacity to build bridges between myself and my students and I am grateful for the gift to learn that FNESC has given me and all teachers. However, this is not a simple exchange. I draw upon the language of gift as a final reflection on what I have learned about the past and future of settler relationality through my inquiry because the term "gift" holds within it some of the complexities that I have shared throughout this discussion and that I think are important to highlight again.

Historically, the gifts offered by First Peoples to the early settlers were accepted in ways that disadvantaged and harmed First Peoples for settler gain. This is not only the context of the past; Tuck and Yang (2012) examine how settler relationality continues to harm Indigenous efforts of decolonization. 
[Decolonization] is not converting Indigenous politics to a Western doctrine of liberation; it is not a philanthropic process of 'helping' the at-risk and alleviating suffering; it is not a generic term for the struggle against oppressive conditions and outcomes. The broad umbrella of social justice may have room underneath for these efforts. By contrast, decolonization specifically requires the repatriation of Indigenous land and life. (p. 21)

Tuck and Yang explain that metaphorical discussions of decolonization are merely efforts to alleviate settler guilt and responsibility without giving up land, power, or privilege, without having to change much at all. Part of accepting the gift of FPPL is embracing the critiques of settlers who, inappropriately, search for closure of the losses of First Peoples.

The ongoing risk of being critiqued for my engagement with FPPL has challenged me, for as Regan (2010) describes,

Sometimes we are offered a gift that we are reluctant to accept. Perhaps we do not recognize it as a gift because it feels like a burden, like a heavy responsibility that we don't quite know how to carry, and we are afraid we will do so poorly. (p. 18)

Through daily, committed action, and growing understanding, I am learning not to respond defensively to critiques, but rather to consider and notice how I can learn from any critique as a way to further disrupt my thinking. In the end, welcoming critique has been one of the most valuable parts of the gift. So, while I may not believe that I seek to reconcile my feelings of guilt or discomfort, as suggested by Tuck and Yang (2012), it will be helpful for me to continually be aware of such a possibility while working with the FPPL in ongoing ways.

My embrace of critical perspective is also an embrace of creative possibilities. My inquiry ignited in me a hopefulness for the future of First Peoples Principles of Learning and this imagining also drew upon the concept of gift. Twenty years ago, Battiste (1998) described how a First Peoples curriculum is like a seed in autumn that can sprout into the beginnings of decolonization in education. The growth of such curricular plans has been slow, but the seeds are now planted, and they have created ripples of change in my teaching practice. The First Peoples Principles of Learning were a vehicle towards a changed teaching practice that focuses on the holistic nature of children and their ways of learning. Thus, despite our history, the gift of FPPL has an opportunity to be understood as more than an exchange; it can be a way of seeing all there is to be deeply grateful for. As Kuokkanen (2007) describes,

Instead of viewing the gift as a form of exchange or as having only an economic function, I argue that the gift is a reflection of a particular worldview characterized by a perspective of the natural environment as a living entity which gives its gifts and abundance to the people if it is treated with respect and gratitude. (p. 61)

Offering my self-inquiry to my community is imbued with a desire to reciprocate and respectfully engage the FPPL, so that it can be a gift with no bounds that provides sustenance as needed. For me, respectful action and appropriate acknowledgment of the authorship of the principles started with self-inquiry and will now continue through actions of decolonization supported by the naming of worldview, and changes in how I tell stories that I have outlined. Through ongoing inquiry, I look forward to learning from my 
colleagues as they articulate their own understanding of FPPL and expect that from the intersections and tensions of these diverse theories, new co-created openings for action and understanding will become accessible.

\section{Note}

1. FNESC also recognizes that the principles and the concept of a First Peoples approach to learning is a prompt to begin or continue a conversation as there is no one pan-First Peoples approach to learning (Chrona, 2014).

\section{References}

Battiste, M. (1998). Enabling the autumn seed: Toward a decolonized approach to Aboriginal knowledge, language, and education. Canadian Journal of Native Education, 22(1), 16-26.

Battiste, M. (2011). Cognitive imperialism and decolonizing research: Modes of transformation. In C. Reilly, V. Russell, L.K. Chehayl, \& M. M. McDermott (Eds.), Surveying borders, boundaries, and contested spaces in curriculum and pedagogy (pp. xv-xxviii). Charlotte, NC: Information Age Publishing.

British Columbia Ministry of Education and First Nations Education Steering Committee (2008). English 12 First Peoples Integrated Resource Package (2008). Retrieved from http://www.bced.gov.bc.ca/abed/documents.htm

British Columbia Ministry of Education. (2015). Introduction to British Columbia's redesigned curriculum. Retrieved from https://curriculum.gov.bc.ca/sites/curriculum.gov.bc.ca/files/pdf/curriculum_intro.pdf.

British Columbia Ministry of Education. (2016). Official redesigned K-9 curricula. Retrieved from https://curriculum.gov.bc.ca

Broom, C. (2016). Power, politics, philosophy, and reform: A historical review of curriculum reform, academia, and government in British Columbia, 1920 to 2000. Journal of Curriculum Studies, 48(5), $711-727$.

Cannon, M. J. (2013). Changing the subject in teacher education: Centering Indigenous, diasporic, and settler colonial relations. Cultural and Pedagogical Inquiry, 4(2), 21-37.

Retrieved from https://ejournals.library.ualberta.ca/index.php/cpi/article/viewFile/19109/1516

Chrona, J. (2015). First Peoples Principles of Learning.

Retrieved from https://firstpeoplesprinciplesoflearning.wordpress.com

Decter, L., \& Issac, J. (2015). Reflections on unsettling narratives of denial. In G. L'Hirondelle Hill \& S. McCall (Eds.). The land we are: Artists \& writers unsettle the politics of reconciliation (pp. 96-129). Winnipeg, MB: ARP Books.

Donald, D. (2009). Forts, curriculum, and Indigenous Métissage: Imagining decolonization of Aboriginal-Canadian relations in educational contexts. First Nations Perspectives, 2(1), 1-24.

Donald, D. (2012). Forts, colonial frontier logics, and Aboriginal-Canadian relations: Imagining decolonizing educational philosophies in Canadian context. In A. Abdi (Ed.), Decolonizing philosophies of education (pp. 91-111). Rotterdam, NL: Sense Publisher. 
The First Peoples Principles of Learning: An Opportunity for Settler Teacher Self-Inquiry

First Nations Education Steering Committee (FNESC). (2008). English 12 First Peoples teacher resource guide. Retrieved from http://www.fnesc.ca/learningfirstpeoples/efp/

First Nations Education Steering Committee (FNESC). (2008/2014). Poster First Peoples Principles of Learning. Retrieved from http://www.fnesc.ca/resources/publications/

Grass, S. (2017). The First Nations Educational Steering Committee and the First Nations School Association's Indian Residential Schools and reconciliation teacher resources. In J. Archibald, Q'um Q'um Xiiem, \& J. Hare (Eds.). Learning knowing sharing: Celebrating success in K-12 Aboriginal education in British Columbia (pp. 4-14). Principals' \& Vice-Principals' Association.

Hanson, K. (2017). Mindful community: Possibilities for teacher professional learning. Lanham, ML: Lexington.

Hargreaves, A., \& Jefferess, D. (2015). Always beginning: Imagining reconciliation. In G. L'Hirondelle Hill \& S. McCall (Eds.). The land we are: Artists \& writers unsettle the politics of reconciliation (pp. 96-129). Winnipeg, MB: ARP Books.

Kuokkanen, R. J. (2007). Reshaping the university: Responsibility, Indigenous epistemes, and the logic of the gift. Vancouver, BC: UBC Press.

Martusewicz, R. (2001). Seeking passage: Post-structuralism, pedagogy, ethics. New York, NY: Teachers College Press

Okanagan Nation Alliance (2013). Go back to the root: A learning resource on Syilx families. Westbank, BC: Okanagan Nation Alliance.

Palmer, P. (1998). Courage to teach. San Francisco, CA: Jossey-Bass.

Regan, P. (2010). Unsettling the settler within: Indian residential schools, truth telling, and reconciliation in Canada. Vancouver, BC: UBC Press.

Sanford, K., Williams, L., Hopper, T., \& McGregor, C. (2013). Indigenous principles decolonizing teacher education: What we have learned. In Education, 18(2), 18-34.

Scott, D. (2013). Teaching Aboriginal perspectives: An investigation into teacher practices amidst curriculum change. Canadian Social Studies, 46(1), 31-43.

Simpson, L. (2014). Land as pedagogy: Nishnaabeg intelligence and rebellious transformation. Decolonization: Indigeneity, Education \& Society, 3(3), 1-25.

Snelgrove, C., Dhamoon, R., \& Corntassel, J. (2014). Unsettling settler colonialism: The discourse and politics of settlers, and solidarity with Indigenous nations. Decolonization: Indigeneity, Education \& Society, 3(2), 1-32.

Tanaka, M. (2016). Learning and teaching together: Weaving Indigenous ways of knowing into education. Vancouver, BC: UBC Press

Tuck, E., \& Yang, K. (2012). Decolonization is not a metaphor. Decolonization: Indigeneity, Education \& Society, 1(1), 1-40.

Veracini, L. (2011). Telling the end of the settler colonial story. In L. Pilkington \& F. Bateman (Eds.), Studies in settler colonialism: Politics, identity, and culture. New York, NY: Palgrave Macmillan. 


\section{Appendix A}

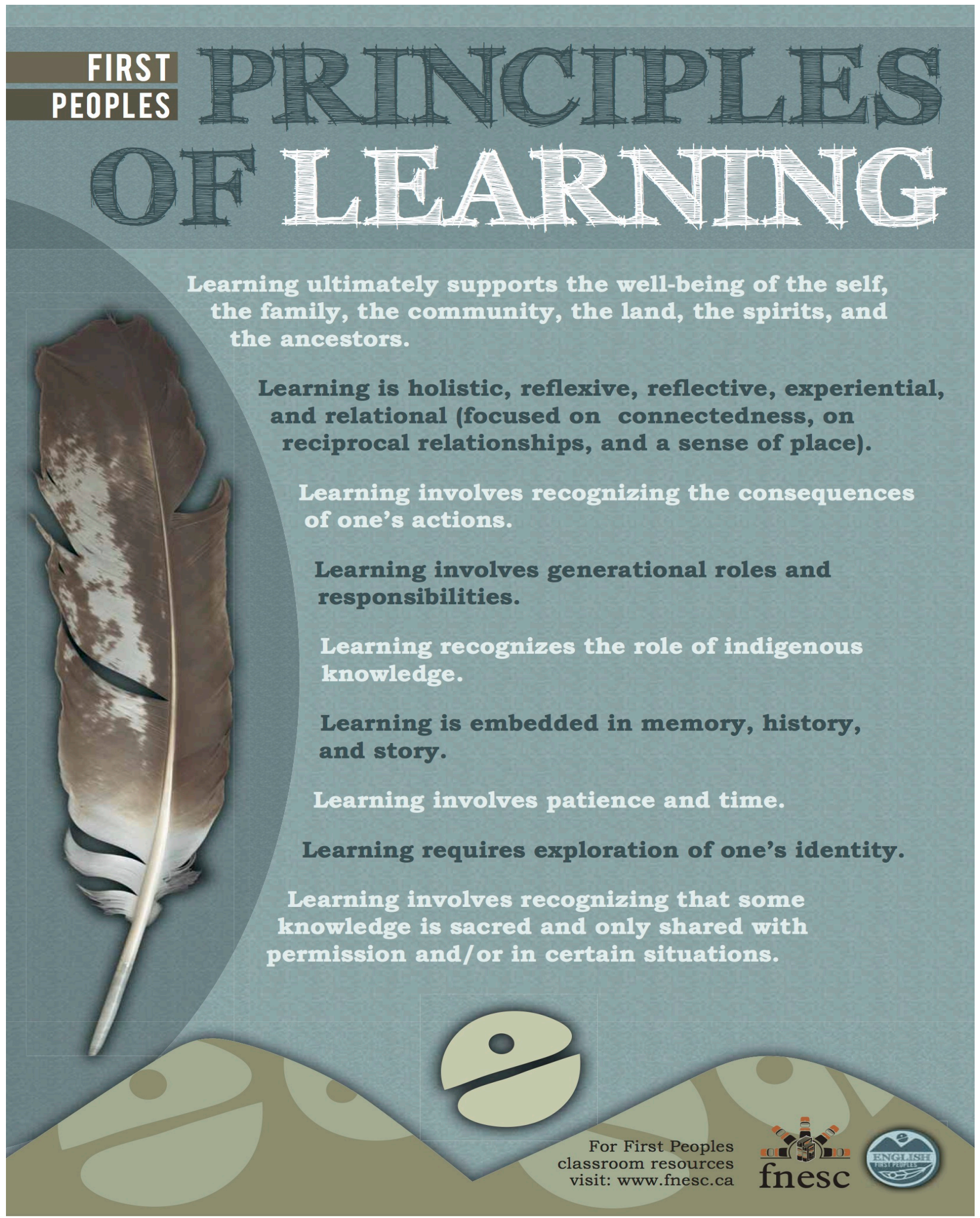


The First Peoples Principles of Learning: An Opportunity for Settler Teacher Self-Inquiry

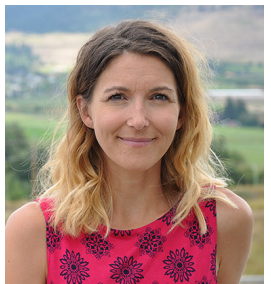

Kelly Hanson has spent over a decade working as a public middle school teacher in British Columbia and Ontario. She is currently a faculty advisor and a doctoral candidate at the University of British Columbia. Kelly's PhD research explores intersections between indigenizing curriculum theory and teacher education and the lives of teachers. 